Article

\title{
System and Cost Analysis of Stand-Alone Solar Home System Applied to a Developing Country
}

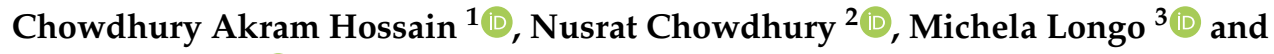 \\ Wahiba Yaïci ${ }^{4, *}$ (D) \\ 1 Department of Electrical and Electronic Engineering, American International University-Bangladesh, \\ Dhaka 1229, Bangladesh; chowdhury.akram@aiub.edu \\ 2 Department of Electrical and Electronic Engineering, Daffodil International University, \\ Dhaka 1207, Bangladesh; nusrat.eee@diu.edu.bd \\ 3 Department of Energy, Politecnico di Milano, 34-20156 Milano, Italy; michela.longo@polimi.it \\ 4 CanmetENERGY Research Centre, Natural Resources Canada, Ottawa, ON K1A 1M1, Canada \\ * Correspondence: wahiba.yaici@canada.ca; Tel.: +1-613-996-3734
}

Received: 17 February 2019; Accepted: 1 March 2019; Published: 6 March 2019

check for updates

\begin{abstract}
Power is one of the key requirements for the development of economies and upgrading of standards of living of developing countries. Countries such as Bangladesh depend largely on fossil fuels such as diesel fuel and natural gas to produce the main proportion of their electricity. However, this country's combination of limited natural gas reserves high fuel prices and escalating costs of transmission and distribution lines has greatly increased the unit cost of electricity generation and it is becoming difficult for customers to pay for electricity. On the other hand, burning fuel causes environmental pollution that leads to global warming which is ultimately responsible for climate change and its devastating consequences. In this study, we have recommended a stand-alone system for the traditional consumption of domestic electric use at residential units in Bangladesh. We have shown a comparison of using the stand-alone photovoltaic (PV) system with the traditional grid connection. Although the initial set-up cost is high, it becomes profitable as people are supplied with electricity, which is being generated from $\mathrm{PV}$ as a result minimizing the energy cost from the grid, and in addition, they can later make savings from this system. This paper, therefore, aims at determining the optimum size of the rooftop solar home system that will fulfil all the criteria for powering up electrical appliances at an affordable price. Comparative analysis of both energy systems based on the cost calculation has been performed by means of the Hybrid Optimization of Multiple Energy Renewables (HOMER) software. The validity of this proposal and its usefulness is also analysed.
\end{abstract}

Keywords: solar home systems (SHS); levelized cost of energy (LCOE); photovoltaic system; HOMER

\section{Introduction}

Bangladesh's economy is mostly dependent on agriculture and its industrial sector. To enhance employment opportunities, policies and incentives were put in place to boost the growth of both these sectors. However, electricity generation and supply in the country is much lower than is required for the growing demand, a shortfall that has impeded sustainability of the country's economic growth. Despite achievements, a large proportion of the country's inhabitants even now does not gain access to power. Per the study carried out by the International Energy Agency (IEA), 1.1 billion persons totally did not get access to electricity in 2016. This represents a decrease of $35 \%$ in the total people compared to 2000 [1]. In Bangladesh only $60 \%$ of the population get access to power and it would require an estimated 15 years to extend the service to every one [2]. Currently, $99 \%$ of energy consumed in rural 
households is based on fossil fuels. Relentlessly, energy demands in the country continue to rise daily and a power crisis has become imminent.

Natural gas plays a crucial role in enabling the country to meet its energy needs. It accounts for $72 \%$ of the total commercial energy use and $82 \%$ of the total electricity produced [3,4]. Nonetheless, limited availability of the resource in the country translates to a deficit of $4.02 \times 10^{6} \mathrm{~m}^{3} /$ day in 2011 . It is estimated that this will rise to $48.54 \times 10^{6} \mathrm{~m}^{3} /$ day by 2019-2020. As a result, Bangladesh will require to complement 19,000 MW of extra power, even if its national GDP increase stays low at $5.5 \%$ until 2025. This factor will likely cause the gas demand to escalate up to $129.32 \times 10^{6} \mathrm{~m}^{3} /$ day by $2019-20$ [5]. In order to resolve the power problem, the national grid's capacity was recently enhanced substantially by the addition of several power-generating units although sustained high demand and increasing pervasive needs for power have minimised these accomplishments and created a serious challenge for power stations. To solve this energy challenge, this paper analyses that renewable energy, is a preferable alternative power source. Since the year of 2010 the reduced cost of electricity from utility-scale solar photovoltaic (PV) projects has been remarkable. The worldwide weighted average levelized cost of power (LCOE) of utility-scale solar PV has fallen 73\% since 2010, to USD 0.10/kWh for new ventures dispatched in 2017, though the non-renewable energy source terminated electricity cost extend in 2017 was assessed to range from USD 0.05 to USD $0.17 / \mathrm{kWh}$, contingent upon the fuel and nation [6]. While investment expenditures of renewable energy are usually higher compared to fossil fuels, this option becomes economically viable when all other factors such as health hazards, environmental problems and lower operating costs are taken into consideration. Increasing the renewable energy usage in the European Union (EU), many directives and agreements have been signed. As the crucial year 2020 is coming back nearer, the European Commission revealed a proposal for a revised Renewable Energy Directive to create the EU a worldwide leader in renewable energy and make sure that the target of a minimum of $27 \%$ renewables within the final energy consumption in the EU by 2030 is met [1]. Bangladesh's Renewable Energy Policy (REP) set targets for exploiting renewable energy resources to meet $5 \%$ of the total power demand by 2015 and $10 \%$ by 2020 [7]. During 2016, a minimum of 75 GW of solar PV capability was added worldwide and at the top of 2016 international solar PV capacity in total had reached 303 GW [1].

The Italian government has effectively implemented the concept of rooftop PV in a project. The project clearly described the calculation for the reimbursement time along with the economic value. Similar type of investigations were also executed in India and Indonesia [8,9]. Many researches have also been performed considering the technical and economic aspects of solar PV system for Bangladesh specially focusing the urban and remote areas [10,11]. A basic solar PV system consists of a small solar panel, a battery, and a charge controller [12]. The system costs approximately $\$ 350$, which can be sourced from a financial institution (preferably a microfinance bank) at a modest rate [13]. Through discussions with local banks and microfinance companies, convenient payment plans can be negotiated, which would ultimately help to finance the large initial investment cost involved in purchasing the new system. It is notable that the government of Bangladesh is currently making efforts to popularize renewable energy and also make it available to ordinary people. Its efforts are complemented by those of private financing companies including the Rural Electrification Board (REB) and the Infrastructure Development Company Limited (IDCOL), which are similarly investing in solar systems.

For different household appliances and lighting purpose, by 2017 a total number of 5.2 million standalone PV systems, which are also known as Solar Home Systems (SHSs) with a capacity of $218 \mathrm{MW}$, were installed. The total capacity of the installed SHSs was $218 \mathrm{MW}$. This information was published in "Renewables 2018-Global Status Report", which is released annually by the Paris-based energy think-tank REN21 in June. In the report it was also mentioned that with a total number of 17 million users, Bangladesh stood the second highest users of SHSs after India with a total of 148 million users. This statistic supports that approximately $13 \%$ of the total population uses electricity provided by SHSs $[14,15]$. 
The world's most abundant and permanent energy source is solar radiation. In every year per minute solar energy received by the surface of the Earth is much greater than the energy utilisation by the entire population. For the time being, solar power, being accessible all over, is enticing for complete systems notably within the rural parts of all the developing nations [8]. Solar energy has a significant potential for success in Bangladesh. The average solar radiation during the year for Bangladesh is $4.57 \mathrm{kWh} / \mathrm{m}^{2} /$ day. The system is endearing because once payment for initial set up is completed, there are no further additional cost for fuel incurred throughout its lifetime. Savings can later be generated through this innovative scheme. Savings, which result from discontinuing the use of candles, kerosene fuel, can be channeled into making the monthly payments whilst at the same time promoting a greener environment.

The software Hybrid Optimization Model for Electric Renewables (HOMER 2.68 beta) [16,17], was utilised as a modelling tool, which in recent years has been employed for optimal sizing and simulations of micro-grids by many researchers in several counties [18-22]. A literature review reveals that many studies were undertaken in various counties on the advantages of rooftop solar off grid system [23-25]. The authors' previous work has contributed to the proposal of a new solar energy system for an electric vehicle system design and for its optimal size using HOMER [26]. In this study, a recommendation that the renewable energy-based rooftop stand-alone solar home system is a viable alternative energy source. According to our knowledge, it appears that no study has been accomplished on such residential system scale for use in developing country, and it assures the novelty of this publication. The objective of the current investigation is to examine the technical and economic feasibility of a rooftop solar home system to evaluation the advantages of users swapping over from grid to solar PV as an alternative source of electric energy. HOMER tool is utilised to specify the optimal size of the equipment taking into account the geographical and meteorological data of the location under study. HOMER applies the net present cost method for ranking the system's suitability.

Therefore, the reminder of the paper is structured as follows. Section 2 gives full details of the rooftop solar home system utilised to generate heat and power. Section 3 provides basic model data such as input data and component specifications for sizing the various system components. Simulation results are discussed in Section 4, including the optimal sizing of the system and the cost analysis. Finally, conclusions are drawn in Section 5.

\section{Rooftop Solar Home System Description}

A rooftop solar home system (Figure 1) may be a possible alternative supply of electrical energy. This method is changing into tremendously popular and is taken into account as a response to the energy drawback within the country's rural areas. Bangladesh is placed between 88.04 and 92.44 degrees east and 20.30 and 26.38 degrees north, a novel location that provides the country prepared access to solar power for trappings and use [2,27]. Indeed, it experiences a minimum of 10 hour of sunlight daily throughout the year. The average solar irradiance of Bangladesh is around $5 \mathrm{kWh} / \mathrm{m}^{2} /$ day $[27,28]$. Since the solar modules solely produce electrical energy throughout the day, it is necessary to store this energy to be used at night time and through cloudy days. Storage systems utilized typically employ rechargeable lead-based batteries, because of their ability to optimally receive energy at each low- and high-input voltages. A battery regulator is installed in to stop overcharging and deep discharges. The solar photovoltaic system can offer battery output voltage of 12- or 24-Volts electricity (DC) in most cases. To supply devices, that are solely obtainable for AC voltage, a power inverter is used. it is important to arrange such a complete PV system which will match the potential energy consumption with the native average solar irradiation, the ensuing energy production and therefore the needed storage capability [29].

The rooftop stand-alone SHS is now very popular in Bangladesh due to its accessibility and relative affordability as discussed earlier. Owing to the high rate of adoption of SHSs in rural areas, researchers generated a list of probable factors that determine an individual's likelihood of purchasing or adopting it. Easy access to loans from several financing companies now makes it possible for the middle- and lower-income groups to afford the SHS. 


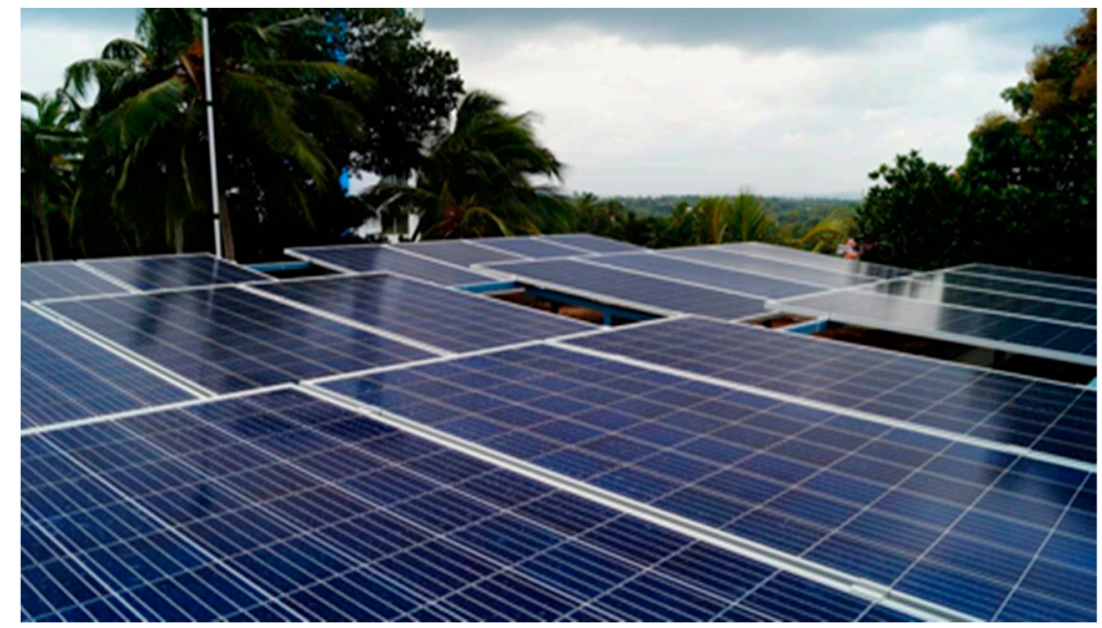

Figure 1. Rooftop solar home system.

The government of Bangladesh has pledged to use $5 \%$ of their electricity using renewable energy sources in 2008 Washington International Renewable Energy Conference. Following that in 2009, a fund of $\$ 29 \mathrm{M}$ was set up by Bangladesh Bank to create public awareness in the solar sector. The central bank also had several agreements with state-owned and private sector banks to provide funds to different financing schemes related with renewable sources with a very low interest rate of about 5\% [30].

Therefore, it appears that the solar home system is systematically becoming more entrenched and established in the country as a viable means of eliminating the collective problems associated with fossil fuels [31].

Promoters of this system perform feasibility and techno-economic analysis to enhance affordability of the SHS. Some innovative financing structures have been developed and are discussed later in this paper. Studies have also been conducted on the cost of energy for the stand-alone SHS system. As mentioned in the previous section, an optimization tool known as HOMER has been used for all the simulation and analysis of the data. The HOMER software, NREL's (National Renewable Energy laboratory), and the micro-power optimization model, can evaluate a range of equipment options over varying constraints and sensitivities to optimise small power systems. HOMER's flexibility is suitable in the assessment of design, planning and decision-making areas for ensuring feasible projects [16,17]. A detailed description of the available mathematical models implemented in HOMER goes beyond the scope of this study. For a comprehensive analysis, the interested readers can refer to the work of Bahramara et al. [18]. After the input data are fed into HOMER, optimal sizes of SHS equipment are established in three stages comprising simulation, optimisation, and sensitivity analysis as illustrated in Figure 2 [16-18]. 


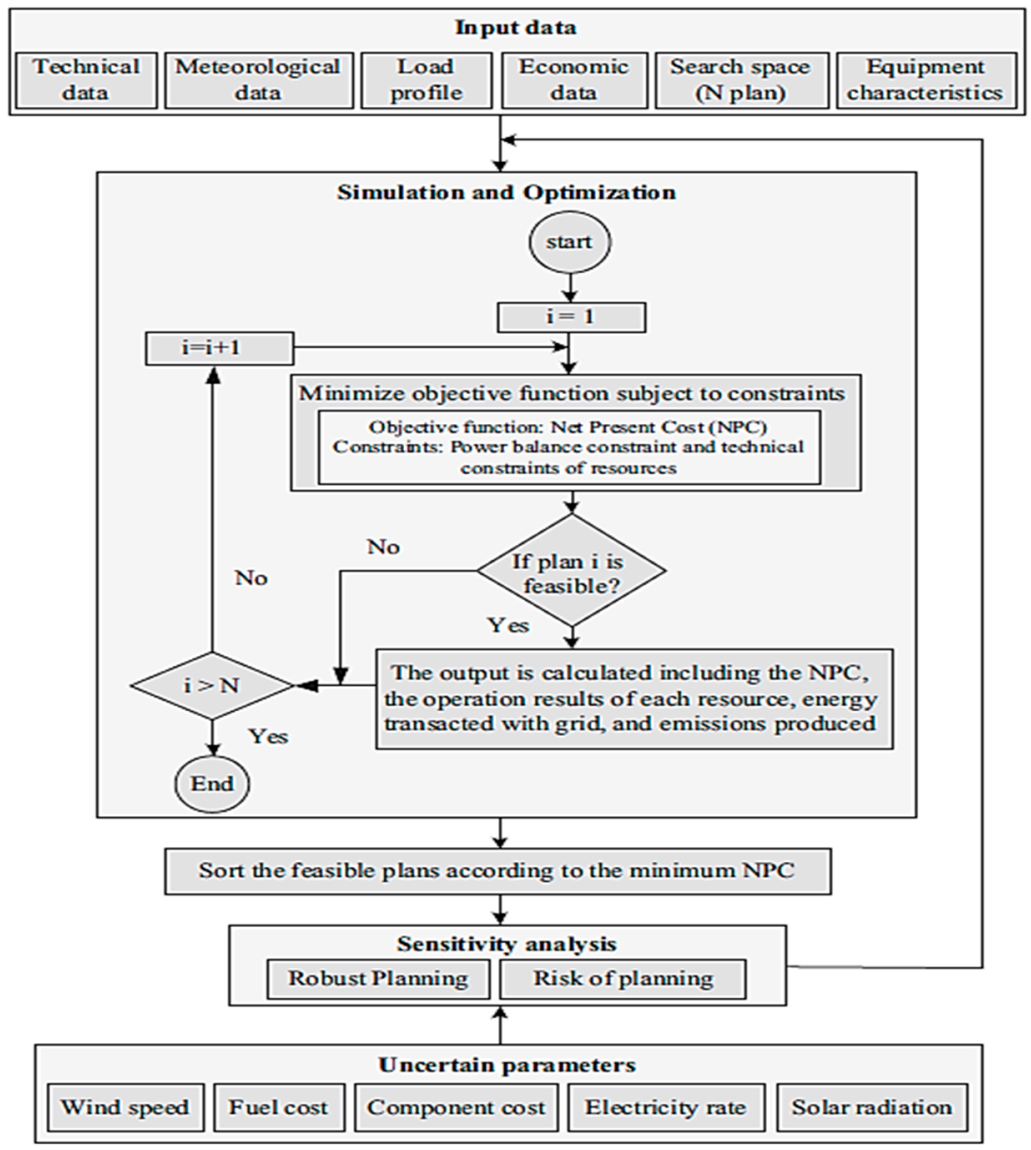

Figure 2. The comprehensive structure of Hybrid Optimization of Multiple Energy Renewables (HOMER) simulation, optimization and sensitivity procedures [18].

\section{Data Collection and Component Specifications}

\subsection{Load Definition}

Consider a typical household, which has 4 CFL (compact fluorescence lamps), 3 alternating current (AC) fans and 1 television (TV). Operating time for the CFL is assumed to be $8 \mathrm{~h} /$ day, fan is $12 \mathrm{~h} /$ day and TV is $4 \mathrm{~h} /$ day. The required power for every CFL is $23 \mathrm{~W}$, AC fan is $80 \mathrm{~W}$, and the TV is $100 \mathrm{~W}$. Therefore, one household requires an approximate load of $432 \mathrm{~W}$. Table 1 describes the average load consumption. It should be mentioned that the consideration of CFL was taken into account based on the typical condition of the proposed research area. The energy efficiency can be increased considering LED lamps and other energy-efficient devices.

Table 1. Average load consumption.

\begin{tabular}{cccc}
\hline Loads & Power Rating [W] & No. of Pieces & Operating [h/day] \\
\hline CFL & 23 & 4 & 8 \\
Fan & 80 & 3 & 12 \\
TV & 100 & 1 & 4 \\
\hline
\end{tabular}

The energy demand per day $\left(E_{d}\right)$ can be calculated as shown in Equation (1):

$$
\mathrm{E}_{\mathrm{d}}=\frac{\sum_{\mathrm{k}=1}^{\mathrm{N}} \mathrm{A}_{\mathrm{k}} \mathrm{P}_{\mathrm{k}} \mathrm{Q}_{\mathrm{k}}}{1000}(\mathrm{kWh})
$$

where: 
$\mathrm{k}=$ Index of each type of load such as fan, lights, TV etc.;

$A_{k}=$ number of hours $\mathrm{k}^{\text {th }}$ device type used per day;

$P_{k}=$ power rating of kth device type;

$Q_{k}=$ number of devices of kth type.

According to the information provided in Table 1, the approximate energy demand per day is $4.02 \mathrm{kWh}$ for each household.

\subsection{Daily Load Profile}

In HOMER according to the load consumption, there is an assumption that off-peak time runs from 12 a.m. to 6 a.m where we consider only fans as a load as it is night time, and therefore the load consumption is almost constant and low during these hours, while the peak time is from 5 p.m. to 11 p.m. The load variation for a day for different months are shown in Figure 3.

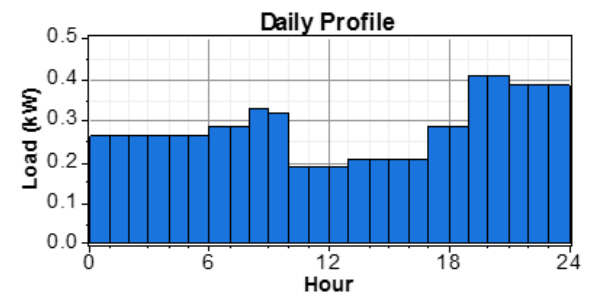

From March to May

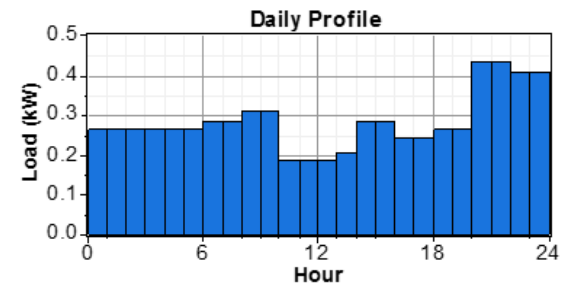

From June to November

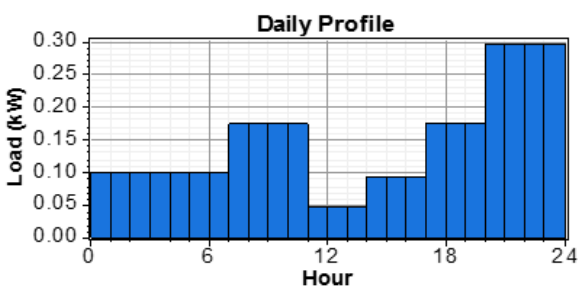

From December to February

Figure 3. Typical daily load profiles.

The seasonal profile for the household load has been represented in Figure 4. It is observed that the maximum value achievable is in June with the value equal to $0.6 \mathrm{~kW}$. Overall, the average value is above $0.4 \mathrm{~kW}$. For January, February and December, the value is low and is around $0.45 \mathrm{~kW}$.

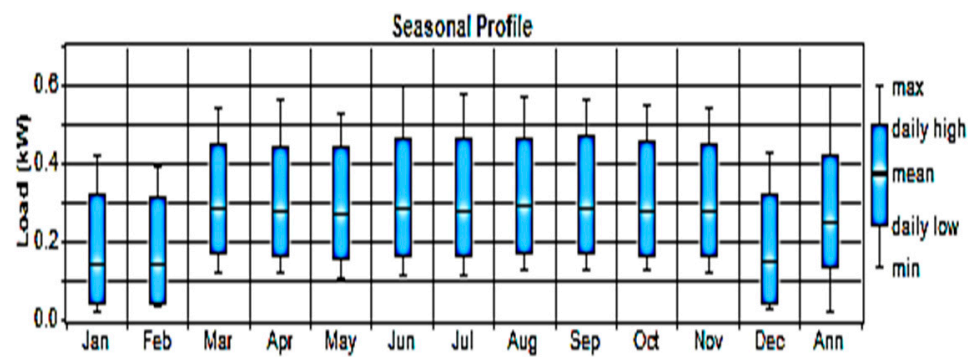

Figure 4. Seasonal load profile.

\subsection{Size Consideration of Photovoltaic Array}

To calculate the PV size, different combinations along with other parameters for panel was given as input in the software to get optimized performance for the proposed system. Here we have considered a lifetime of 25 years for the PV with no tracking system. The cost of the PV has been considered as $\$ 0.36 / W_{P}$ [32]. For the other costs such as installation we have considered $\$ 360$, and for 
operation/maintenance $\$ 5 /$ year considering the standard current market value. Eq. (2) has been used to find the PV generation capacity.

$$
P V_{\text {capcity }}=\frac{E_{d}}{I_{d} \times d}(k W)
$$

where:

$I_{d}=$ average number of hours the sun shines;

$\mathrm{d}=$ de-rating factor, which takes into account the effects of efficiency and changes in the solar generation during the day.

The typical values of $I_{d}$ and $\mathrm{d}$ are $5 \mathrm{~h}$ and $80 \%$, respectively in Bangladesh.

\subsection{Battery Size}

Electricity is supplied from battery at night and also used in emergency situations such as bad weather. This study considered a battery which has nominal voltage of $12 \mathrm{~V}$, and a nominal capacity of $200 \mathrm{Ah}(2.4 \mathrm{kWh})$. The lifetime of battery is assumed to be five years. The installation, replacement, operating and maintenance costs of one battery are taken as $\$ 180, \$ 180$ and $\$ 7 /$ year, respectively [32]. The number of batteries can be determined using the following mathematical equation:

$$
N_{\text {Batteries }}=\frac{E_{d} \times n_{d}}{V_{\text {battery }} \times A H \times D O D}
$$

where:

$n_{d}=$ the number of days of backup power required;

$V_{\text {battery }}=$ the battery voltage rating;

$\mathrm{AH}=$ the ampere-hour rating;

and DOD is the depth of discharge of the battery system.

\subsection{Charge Controller}

A charge controller is similar to the voltage regulator. It regulates the voltage and current that is emitted from the solar panels and going into the battery. Mainly " 12 Volt" panels are set to about 16 to 20 volts, so if there is no voltage regulation the batteries face the risks of being damaged from overcharging. Thus, the charge controller protects against overly high voltage, over current, short circuit, polarity reverse and lighting. The LCD display indicates levels of voltage, current and short circuit. This study considered a charge controller, which is priced at $\$ 70$ [32]. This is an electronic device which guarantees longer lifespan if properly used in the system and thereby helps reduce the cost of the system.

\subsection{Inverter}

An inverter is utilised to convert the power from DC to AC. For 1-kw inverter the installation and replacement costs are considered as $\$ 310$ and $\$ 310$, respectively [32]. Various sizes of inverters are applied in the system. The lifetime of an inverter is taken to be 15 years with an efficiency of $90 \%$. As this is power electronics, a higher lifespan can be utilised.

\subsection{Solar Radiation and Clearness Index}

Bangladesh's geographical location in terms of latitude and longitude are $23^{\circ} 59^{\prime} \mathrm{N}$ and $90^{\circ} 27^{\prime} \mathrm{E}$ respectively. The scaled annual average radiation (Figure 5) for Bangladesh is five $\mathrm{kWh} / \mathrm{m}^{2} /$ day. 


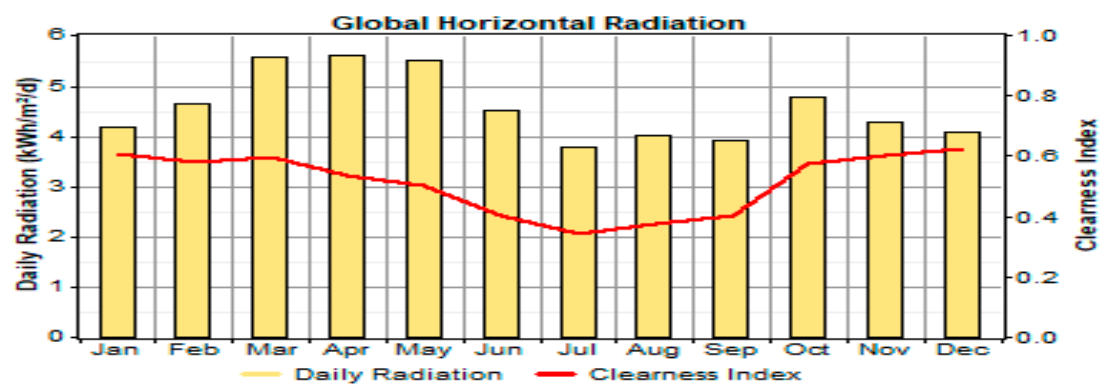

Figure 5. Clearness index and average daily solar radiation.

It should be well noted that using the Solar Resource window in HOMER we can enter the value for either the average radiation or the average clearness index. If any of the value is provided then the other one is automatically calculated. On the other hand, the clearness index is given in a scale of 0 and 1 which give provides the fraction of the solar radiating striking the top of the atmosphere which can reach the Earth's surface. Equation (4) defines the monthly average clearness index:

$$
\mathrm{K}_{\mathrm{T}}=\frac{\mathrm{H}_{\mathrm{ave}}}{\mathrm{H}_{\mathrm{o}, \mathrm{ave}}}
$$

where:

$\mathrm{H}_{\text {ave }}=$ monthly average radiation on the horizontal surface of the earth $\left[\mathrm{kWh} / \mathrm{m}^{2} /\right.$ day $]$;

$\mathrm{H}_{\mathrm{o}, \text { ave }}$ is extra-terrestrial horizontal radiation, meaning the radiation on a horizontal surface at the top of the Earth's atmosphere $\left[\mathrm{kWh} / \mathrm{m}^{2} /\right.$ day $]$.

\section{Results and Discussion}

\subsection{System Analysis}

The system is fed by solar PV arrays and batteries and it will be installed in the rooftop of households as depicted in Figure 6. There is no grid connection in the system. In this system, during the day, the PV array supplies power to the load directly and also charges the battery. At any time, day or night, the load is able to draw power from the battery. The charge controller prevents excessive overcharging and deep discharging of the battery.

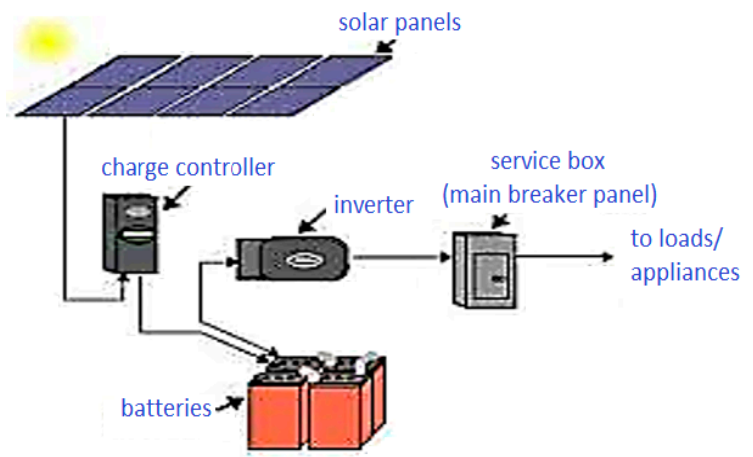

Figure 6. Block diagram of stand-alone SHS.

The total solar home system is designed in HOMER. In HOMER, we have considered 10\% day-to-day load variation. Considering the noise, system loss and random variability of the load, the system is designed for $602 \mathrm{~W}$ peak load, which is much higher than the actual load consumption mentioned in Section 3.1. The daily energy consumption is considered to be $6 \mathrm{kWh}$ for the proposed case.

The system under study is based on AC load, which is supplied by PV and at night or emergency backup battery is used. For AC supply, an inverter is used which converts the DC power that is 
obtained from PV and battery into AC power. For system analysis this model is ran by HOMER and after simulation with best possible combinations, we get the following optimum result shown in Figure 7 for this system.

\begin{tabular}{|c|c|c|c|c|c|c|c|c|}
\hline 4 平 & $\begin{array}{c}\text { PV } \\
(\mathrm{kW})\end{array}$ & 6FM200D & $\begin{array}{l}\text { Conv. } \\
(\mathrm{kW})\end{array}$ & $\begin{array}{l}\text { Initial } \\
\text { Capital }\end{array}$ & $\begin{array}{c}\text { Operating } \\
\text { Cost }(\$ / y r)\end{array}$ & $\begin{array}{l}\text { Total } \\
\text { NPC }\end{array}$ & $\begin{array}{c}\mathrm{COE} \\
(\$ / \mathrm{kWh})\end{array}$ & $\begin{array}{l}\text { Ren. } \\
\text { Frac. }\end{array}$ \\
\hline 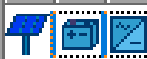 & 2.0 & 8 & 1.0 & $\$ 2,77$ & 302 & $\$ 10,331$ & 0.211 & 1.00 \\
\hline$\dddot{\square}$ & 3.0 & 4 & 2.0 & $\$ 2,72$ & 305 & $\$ 10,347$ & 0.212 & 1.00 \\
\hline$P$ & 2.0 & 6 & 2.0 & $\$ 2,72$ & 308 & $\$ 10,426$ & 0.217 & 1.00 \\
\hline
\end{tabular}

Figure 7. Optimised result from HOMER.

From the HOMER analysis, the optimal result is attained for the arrangement of $2 \mathrm{~kW}$ PV panels, $1 \mathrm{~kW}$ inverter and 8 batteries (each has $200 \mathrm{Ah}, 12 \mathrm{~V}$ ). This result is based on the lowest LCOE and operating cost for SHS.

To calculate the LCOE, which is expressed as the average cost per kWh of useful electrical energy generated by the system, HOMER divides the annualised cost of generating electricity (the cost of serving the load (Cs) subtracted from the total annualised cost $(A n C)$ by the total useful electric energy production (WT). In HOMER, a $6 \%$ annual real interest rate is considered. Hence, it calculates the LCOE using Equation (5):

$$
L C O E=\frac{(A n C-C s)}{W T}
$$

where $\mathrm{LCOE}=0.211 \$ / \mathrm{kWh}(16.88 \mathrm{Tk} / \mathrm{kWh})$.

The total system's power is supplied by $2 \mathrm{~kW}_{\mathrm{p}} \mathrm{PV}, 24 \mathrm{~V}$ system with 4 panels in parallel to maintain the PV voltage $24 \mathrm{~V}$ and 4 string of batteries (each string has two $12 \mathrm{~V}, 200$ Ah batteries connected in series) to meet the load demand with one charge controller and an inverter. Figure 8 presents average monthly production of SHS throughout the year. It is clear that production of the solar power varies with respect to different seasons, but it always produces enough necessary power. From the monthly electrical production, it can be seen that the production is high from March to June.

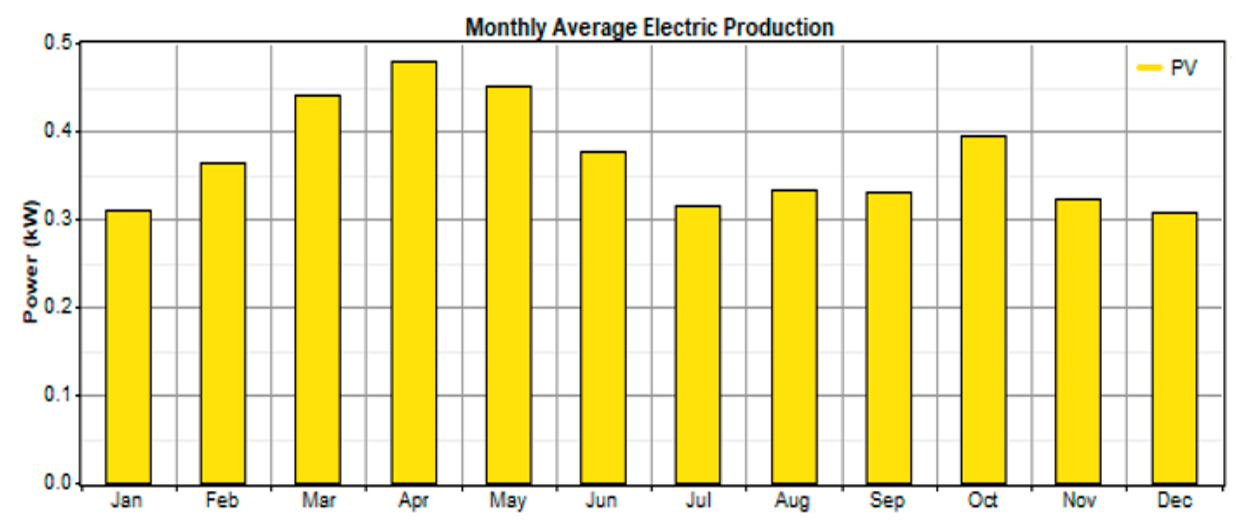

Figure 8. Monthly average electrical production SHS.

It can be calculated from the input data that this system will be producing a total of $3232 \mathrm{kWh} / \mathrm{yr}$ from the PV system and the consumption of the proposed system will be around $1959 \mathrm{kWh} / \mathrm{yr}$, which allows us to conclude that the proposed system will be producing enough power for additional electrical equipment to use. The total power surplus from the system is equal to $1273 \mathrm{kWh} / \mathrm{yr}$, which can be sold to or shared with neighbours under certain conditions. 


\subsection{Cost Analysis}

In the existing grid connection system if the user paid the monthly electricity for 180 units ( 6 units per day) then the total cost of the utility power from the grid $\left(C_{\text {Grid }}\right)$ can be calculated using Equation (6):

$$
C_{\text {Grid }}=365 \times E_{d} \times C_{\text {unit }} \times L
$$

where:

$C_{\text {unit }}=$ the cost of per unit energy and $\mathrm{L}$ is the project lifetime.

Therefore, the total electricity bill for 25 years for grid-connected supply without using solar connection is $\$ 3901$ (312,075 Tk) considering per unit cost of utility is $\$ 0.0713$ (5.7 Tk). On the other hand, the total cost of the rooftop solar system without taking into account any subsidy $\left(C_{p v}\right)$ can be evaluated using Equation (7):

$$
C_{p v}(\text { without subsidy })=C_{P V} \text { panel }+C_{\text {battery }}+C_{\text {inverter }}+C_{\text {Charge controller }}+C_{\text {others }}
$$

where:

$C_{P V \text { panel }}, C_{\text {battery }}, C_{\text {inverter }}, C_{\text {Charge controller }}$ are the capital costs of $P V$, battery, inverter and charge controller, respectively. The other system capital cost is denoted by $C_{\text {others }}$.

The initial cost of this proposed rooftop PV system is $\$ 2770$ (221,600 Tk). Thus, the overall profit during the full project life realised by switching from utility grid connection to rooftop solar PV system is $\$ 1131$ (90,480 Tk). Accordingly, the payback period can be calculated using Equation (8):

$$
\text { Payback Period }=\frac{C_{p v}}{E_{d} \times C_{u n i t} \times 365}(y r)
$$

If users replace their existing system with rooftop solar home system, then within 18 years they can recover their initial cost; that means the payback period is 18 years. Here in the rooftop PV system no subsidy has been considered for that reason the payback period is much higher. If we consider $40 \%$ government subsidy as per process, then the payback period will be much lower than the present value. Therefore, by adopting this proposed system users can save their money and improve their economic conditions. In a SHS, generally a large portion of cost around $80 \%$ of total cost has been added because of the battery and its short lifespan. The cost summary of the proposed project is shown in Figure 9.

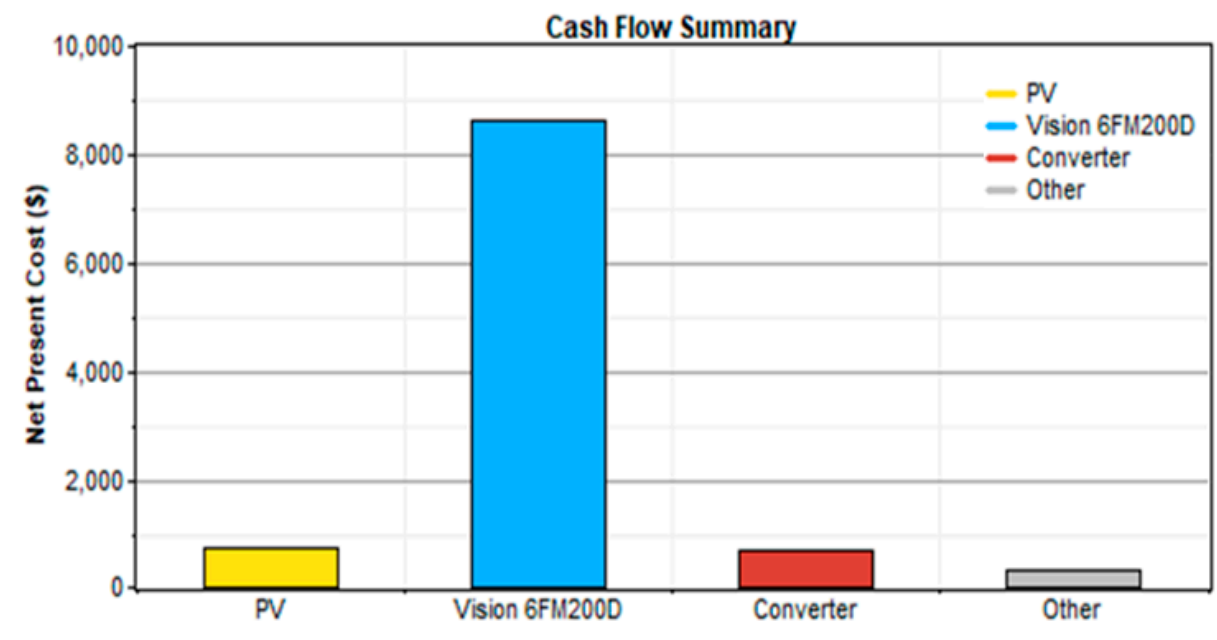

Figure 9. Cash flow summary of SHS over lifespan. 
From the cost summary displayed in Figure 9, it can be seen that the bulk of expenses is due to the specific battery model 6FM200D. The long lifespan of PV cells and converter contribute to the system's feasibility for use. Figure 10 presents the yearly cash flow of each component of SHS for the lifespan.

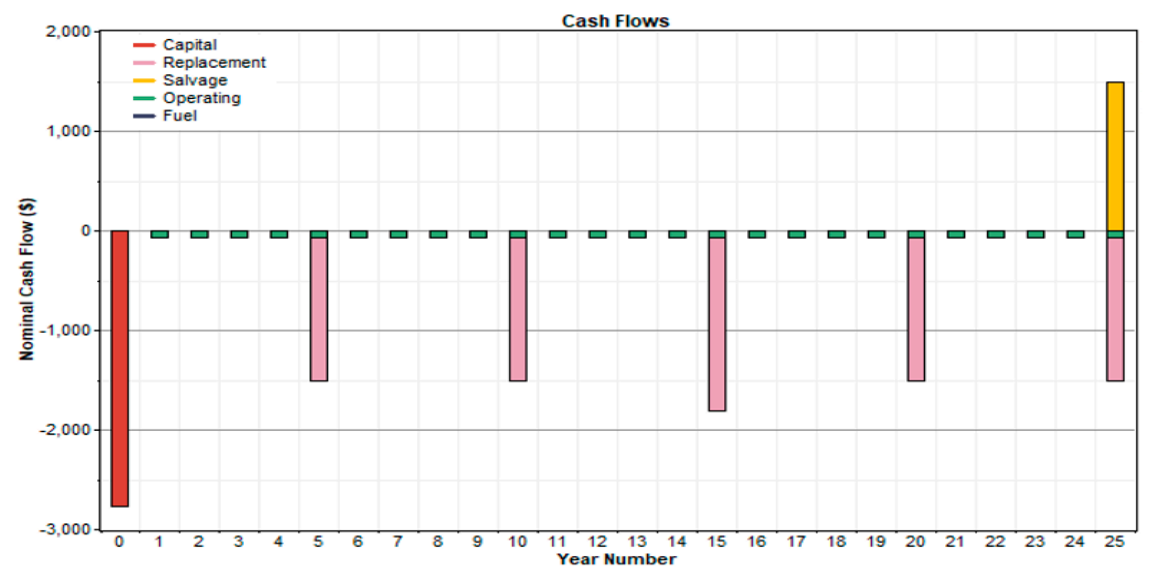

Figure 10. Cash flow of SHS for entire life span.

The cash flow diagram provides us a clear idea of the typical expenses of different components of SHS. For our system, a user will initially need to spend a fairly amount of money and then spend smaller amounts periodically. It is important to note that every five years users will need to replenish the battery because of its limited lifespan. The inverter and charge controller cost will add once 15 year is passed and at the end of the life span of the system salvage value will return or the system will be replaced completely. The nominal cost of the system is also mentioned for every year, which includes periodic servicing of the inverters and cleaning the panels.

\subsection{Environmental Impacts}

According to the $\mathrm{CO}_{2}$ baseline database [33] prepared by the Department of Environment, Government of People's Republic of Bangladesh, the weighted average grid emission factor (GEF) for power plants is 0.67 Tonnes of $\mathrm{CO}_{2}$ per $\mathrm{MWh}$ of energy generated. Using this factor, we can determine the reduction of $\mathrm{CO}_{2}$ emissions because of shifting to rooftop solar for a lifetime of 25 years as disclosed in Equation (9).

$$
\mathrm{CO}_{2}(\text { Emission })=\frac{E_{d} \times 0.67 \times 365 \times 25}{1000}(t / \mathrm{Mwh})
$$

In the proposed rooftop PV system, we can reduce 36.68 tonnes $\mathrm{CO}_{2}$ emissions during the 25 years of project life. Therefore, we can reveal that beside the monetary benefit it should also be mentioned that the current grid supply that is generated from the fossil fuel as a result of the $\mathrm{CO}_{2}$ emissions is much higher. Whereas using the proposed stand-alone system can reduce the demand of energy from the grid as a result reducing the overall $\mathrm{CO}_{2}$ emissions.

\section{Conclusions}

This paper highlighted the benefits of using a rooftop stand-alone Solar Home System both to minimise energy costs, and as a viable alternative to fossil fuels. The study demonstrated that by using this system, the total cost of energy will be decreased as the per unit cost is around $\$ 0.211$ (16.88 Tk) and that there would gradually be no more additional fuel charges for consuming energy. In fact, within a few years, income can be earned by installing this rooftop stand-alone Solar Home System. The system is further endeared by availability of financing options that payment and installation of this system. From our cost analysis, users can approach micro finance companies or obtain loans from commercial banks. The analysis also illustrated that Bangladesh has surplus energy, which can be shared. The system can be improved by the installation of PV in between open neighbouring places for 
more daylight. Through this method, many off-grid areas will gain light sources. Further, total load pressure on the electricity grid network will also be reduced. Bangladesh is a developing country and conventional energy sources may no longer be feasible in the future in view of increasing fuel costs and environmental concerns. The rooftop SHS system can minimise the load pressure on the fuel system, which ultimately reduces greenhouse gas emissions and can contribute to a greener environment. Finally, in undertaking this scheme, people can be enlightened about all its benefits including the potential for income savings, which would ultimately enhance the economic activities of the people without any adverse effects on the environment.

Author Contributions: C.A.H. and N.C. proposed the core idea, developed the models. They performed the simulations, exported the results and analysed the data. W.Y. and M.L. revised the paper. C.A.H., N.C., M.L. and W.Y. contributed to the design of the models and the writing of this manuscript.

Funding: This research received no external funding. The APC was funded by Natural Resources Canada and by W. Yaïci.

Conflicts of Interest: The authors declare no conflict of interest.

\section{References}

1. Golub, V.; Raff, R.; Topic, D. Optimization of an off-Grid PV System in Respect to the Capacity Shortage Value. In Proceedings of the 2018 IEEE PES Innovative Smart Grid Technologies Conference Europe (ISGT-Europe), Sarajevo, Bosnia and Herzegovina, 21-25 October 2018; pp. 1-6.

2. Islam, M.Z.; Mashsharat, A.; Mim, M.S.; Rafy, M.F.; Pervei, M.S.; Rahman Ahad, M.A. A Study of Solar Home System in Bangladesh: Current Status, Future Prospect and Constraints. In Proceedings of the 2nd International Conference on Green Energy and Technology, Dhaka, Bangladesh, 5-6 September 2014; pp. 110-115.

3. International Energy Agency, World Energy Outlook, Executive Summary. 2008. Available online: https: //www.eia.gov/outlooks/ieo/pdf/exec_summ.pdf (accessed on 10 February 2019).

4. Flavian, C.; Aeck, M.H. The potential role of renewable energy in meeting the millennium development goals. In REN21 Network; The Worldwatch Institute: Washington, DC, USA, 2005.

5. Khan, S. The search for alternatives. Star Weekend Magazine, Volume 8, 5 April 2009.

6. Renewable Power Generation Costs in 2017, IRENA, International Renewable Energy Agency. Executive Summary. Available online: https://www.irena.org/-/media/Files/IRENA/ Agency/Publication/2018/Jan/IRENA_2017_Power_Costs_2018_summary.pdf?la=en\&hash= 6A74B8D3F7931DEF00AB88BD3B339CAE180D11C3 (accessed on 27 December 2018).

7. Bangladesh Power Development Board. Available online: http://www.bpdb.gov.bd/bpdb/index.php? option=com_content\&view=article\&id=26 (accessed on 10 February 2019).

8. Kumar, S.; Taneja, L.; Kaur, R. Design and control of residential off-grid connected PV systems. In Proceedings of the 2015 International Conference on Recent Developments in Control, Automation and Power Engineering (RDCAPE), Noida, India, 12-13 March 2015; pp. 204-208.

9. Hiendro, A.; Kurnianto, R.; Rajagukguk, M.; Simanjuntak, Y.M.; Junaidi. Techno-economic analysis of photovoltaic/wind hybrid system for on shore/remote area in Indonesia. Energy 2013, 59, 652-657. [CrossRef]

10. Sharma, P.; Bojja, H.; Yemula, P. Techno-economic analysis of off-grid rooftop solar PV system. In Proceedings of the 2016 IEEE 6th International Conference on Power Systems (ICPS), New Delhi, India, 4-5 March 2016; pp. 1-5.

11. Kumar Nandi, S.; Ranjan Ghosh, H. Techno-economical analysis of off-grid hybrid systems at Kutubdia Island, Bangladesh. Energy Policy 2010, 38, 976-980. [CrossRef]

12. Longo, M.; Roscia, M.; Lazaroiu, G.C.; Pagano, M. Analysis of sustainable and competitive energy system. In Proceedings of the 3rd International Conference on Renewable Energy Research and Applications, ICRERA 2014, Milwaukee, WI, USA, 19-22 October 2014; pp. 80-86.

13. Make Your Home Energy Efficient. Available online: http://www.makeyourhomeenergyefficient.com/ solar-home-appliances.html (accessed on 10 February 2019).

14. Renewables 2018-Global Status Report. Available online: www.ren21.net/wp-content/.../2018/06/17-8652 GSR2018_FullReport_web_final_.pdf (accessed on 3 February 2019). 
15. Renewable Energy Projects, IDCOL Solar Energy Program. August 2013. Available online: http:/ / www. idcol.org/prjshsm2004.php (accessed on 10 February 2019).

16. Getting Started Guide for HOMER Legacy (Version 2.68), January 2011. Available online: http://www. science.smith.edu/ \{\}jcardell/Courses/EGR325/Readings/HOMERGettingStartedGuide.pdf (accessed on 6 December 2018).

17. Givler, T.; Lilienthal, P. Using HOMER®Software, NREL's Micropower Optimization Model, to Explore the Role of Gen-sets in Small Solar Power Systems; Technical Report NREL/TP-710-36774; National Renewable Energy Laboratory: Golden, CO, USA, May 2005.

18. Bahramara, S.; Moghaddam, M.P.; Haghifam, M.R. Optimal planning of hybrid renewable energy systems using HOMER: A review. Renew. Sustain. Energy Rev. 2016, 62, 609-620. [CrossRef]

19. Nandi, S.K.; Ghosh, H.R. Prospect of wind-PV-battery hybrid power system as an alternative to grid extension in Bangladesh. Energy 2010, 35, 2047-3040. [CrossRef]

20. Bekele, G.; Palm, B. Feasibility study for a stand-alone solar-wind-based hybrid energy system for application in Ethiopia. Appl. Energy 2010, 87, 487-495. [CrossRef]

21. Sen, R.; Bhattacharyya, S.C. Off-grid electricity generation with renewable energy technologies in India: An application of HOMER. Renew. Energy 2014, 62, 388-398. [CrossRef]

22. Adaramola, M.S.; Paul, S.S.; Oyewola, O.M. Assessment of decentralized hybrid PV solar-diesel power system for applications in Northern part of Nigeria. Energy Sustain Dev 2014, 19, 72-82. [CrossRef]

23. Ramli, M.A.M.; Hiendro, A.; Sedraoui, K.; Twaha, S. Optimal sizing of grid-connected photovoltaic energy system in Saudi Arabia. Renew. Energy 2015, 75, 489-495. [CrossRef]

24. Roy, P.; Arafat, Y.; Upama, M.B.; Hoque, A. Technical and financial aspects of solar PV system for city dwellers of Bangladesh where green energy installation is mandatory to get utility power supply. In Proceedings of the 2012 7th International Conference on Electrical and Computer Engineering (ICECE), Dhaka, Bangladesh, 20-22 December 2012; pp. 916-919.

25. Yodkhuanga, A.; Ngaopitakkul, A. Performance Evaluation of Solar Rooftop System. In Proceedings of the 3rd IIAE International Conference on Intelligent Systems and Image Processing, Fukuoka, Japan, 2-5 September 2015; pp. 288-293. [CrossRef]

26. Chowdhury, N.; Hossain, C.A.; Longo, M.; Yaïci, W. Optimization of Solar Energy System for the Electric Vehicle at University Campus in Dhaka, Bangladesh. Energies 2018, 11, 2433. [CrossRef]

27. Amin, A.; Sultana, A.; Hasan, J.; Islam, M.T.; Khan, F. Solar home system in Bangladesh: Prospects, challenges and constraints. In Proceedings of the 2014 3rd International Conference on the Developments in Renewable Energy Technology (ICDRET), Dhaka, Bangladesh, 29-31 May 2014; pp. 1-5.

28. Hasan, F.; Hossain, Z.; Rahman, M.; Ar Rahman, S. Design and Development of a Cost Effective Urban Residential Solar PV System. In Proceedings of the 3rd International Conference on the Developments in Renewable Energy Technology, Dhaka, Bangladesh, 29-31 May 2014.

29. Shariar, K.F.; Ovy, E.G.; Hossainy, K.T.A. Closed Environment Design of Solar Collector Trough using lenss and reflectors. In Proceedings of the World Renewable Energy Congress 2011, Linkoping, Sweden, 8-13 May 2011.

30. The Basics of Solar Power for Producing Electricity [online]. Available online: http:/ /www.sunforceproducts. com/Support\%20Section/Solar\%20Panel\%20\&\%20Charge\%20Controllers/The\%20Basics\%20of\% 20Solar\%20Power\%20for\%20Producing\%20Electricity.pdf (accessed on 6 December 2018).

31. Jahan, N.; Hasan, M.A.; Hossain, M.T.; Subayer, N. Present Status of Installed Solar Energy for Generation of Electricity in Bangladesh. Int. J. Sci. Eng. Res. 2013, 4, 604-608.

32. Alibaba.com. Available online: https://www.alibaba.com (accessed on 16 February 2019).

33. Department of Environment, Government of People's Republic of Bangladesh. Available online: http:// www.doe.gov.bd/site/notices / 059ddf35-53d3-49a7-8ce6-175320cd59f1/Grid-Emission-FactorGEF-of-bd (accessed on 10 February 2019).

(C) 2019 by the authors. Licensee MDPI, Basel, Switzerland. This article is an open access article distributed under the terms and conditions of the Creative Commons Attribution (CC BY) license (http:/ / creativecommons.org/licenses/by/4.0/). 